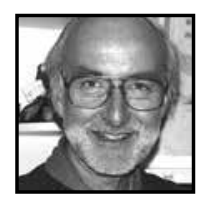

\title{
Commentary \\ The Key to Arts Education: First Inspire the Teachers
}

\author{
Michael Wilson
}

\section{ABSTRACT}

In this interview, Michael Wilson describes the focus of his work with generalist teacher candidates as motivating them to want to teach the arts. He does this by creating situations where the candidates can experience their creative or aesthetic nature. Dr. Wilson explains that the teachers have to believe that the experience itself is important, before they will want to have those kinds of experiences with their students. Another important concept he discusses is the idea that students have to be emotionally ready to learn and that part of the teacher's role is to nourish that emotional readiness. He goes on to explain that many approaches that have been used in arts education for some time are now becoming more recognized in education in general.

How did you become involved in arts education and what has been your goal over the years?

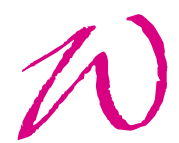
ell, I originally wanted to be a musician. I wanted to be a jazz trumpet player. In fact, my undergraduate years were spent at McGill and I nearly lost my degree because it wasn't McGill I discovered, it was Montreal that I discovered. And I got involved somewhat in the amateur jazz music scene there and I decided I wanted to become a professional jazz trumpet player. I wanted to be the next Miles Davis. But as we all know, Miles Davis became the next Miles Davis. And so I realized that I was good enough to play in the club that I was playing in in Montreal, but not good enough to ever get out of that club_l'd reached my ceiling. 
I decided at age 21 or 22 I wasn't going to do that and I just happened to notice a brochure at the University of Toronto about going to teacher's college, and being able to do the arts as a teachable area of study... and I went there for a year. So that's how I stumbled into teaching — I taught drama for a while - and I didn't want to teach music because it was too personal to me as a musician. My interest in theatre was more tertiary and I did it more for fun and I was prepared to teach that. So, I started my lessthan-illustrious teaching career as a drama teacher in 1965, and I taught for about 24 years in various schools, mostly in Ottawa. And I'd always become interested in teacher education at the time-I always took student teachers when I was a classroom teacher, and I found myself enjoying that process—-working with student teachers-as much as I did teaching students.

I had an opportunity to teach at Queen's University for a while at the end of the 70s, so I did that. I've been at this place [University of Ottawa] since 1989, so that's how I stumbled into it all, and I've since come to think that (in terms of arts education) if you want inspired arts educations in schools, you have to inspire the teachers to teach it. From that day until now, I felt my job was mostly to motivate generalist classroom teachers, especially at the elementary level, to want to teach the arts; to want to do them. It's a motivational thing. And I have taught speciality subjects here, for secondary school teachers, but that's a different process. You're dealing with people already with a background, so what you're actually doing is honing in on the pedagogical skills related to whatever the art form is. But I was more interested in taking generalist teachers, in other words elementary teachers, many of whom had no experience in any of the arts, certainly not them all, and most of whom did not feel they were "talented," and that the arts were for the "talented." I wanted to ignite a fire under them and to this day that's mostly what I want to do-is motivate teachers to want to do that. It's a little bit like Ken Robinson's thing called "The Element," when your skill set matches your motivation set. And I guess that came to me quite late in life: the whole thing of feeling that what I could contribute most is that fact of taking a group of generalist student teachers, having them see something of themselves, something of their aesthetic creative selves, so that they would want to share those kinds of experiences with their students.

\section{How do you do that? How do you motivate these students?}

I try to give them experiences, including this morning; I just taught a class this morning. I try to give them experiences of a creative and/or aesthetic nature, that they confront themselves...I don't try to make them pretend they're ten-year-olds or twelve-year-olds. I try to relate to them as the adults that they are, many of whom are 
accomplished in many areas before they come here, mostly not in the arts, though. I try to make them confront something of their aesthetic selves in what we do. In other words, I try to give them experiences of beauty for themselves; and then we reflect upon that and I ask them to see if they can make that connection to trying to have those kinds of experiences provided for their own students. So I can list what in fact I do mechanically, but in general that's what I try to do. Of course, the course requirements of all the courses here (as I'm sure at McGill and other places), there are lots of bits of information that you should know, the curriculum and all that kind of thing. And of course we touch on that, but mostly they're adults and they can read all that, so I provide them the links to that information. But I think what's most important, particularly for people who are not experts in the arts, it's no good teaching them the pedagogical skills if they don't believe that the experience itself is important.

\section{Can you describe one of the things that you do with them in a little more detail?}

Well, I'll give you one example. In musical terms, I'm very much influenced by the work of Murray Schafer, and he invented a word called, "soundscapes," which a lot of people use in a variety of settings. What Murray Schafer meant by that term "soundscapes" is "an exploration through sound of an environment, an idea or concept, or feeling - or a mix of all of those." That's his concept of music. So, I find that appealing because you don't need to have any training in the western European notational system, you don't need to have any sense of whether you can sing in key or not, or whether you can play a tuned instrument or not. None of that matters. All that matters is whether or not you can explore your own concept of sound. So I do several exercises in exploring what a soundscape is, so in various groups they create sounds related to a topic that I gave to them and they share them with other people in the class-when their eyes are closed and when they're seated in a certain kind of way, so the sound creators can surround them to give them a quadrophonic sonic experience. And I try to give them that experience so that both the performing groups have that experience of deliberately presenting sounds to others; and the other group with their eyes closed can concentrate on listening to these sounds and have the effect of these sounds, transport them somewhere else: to another place, to another set of feelings, concepts of ideas.

Anyway, there's one example which is as purely important music as anything else in music, but it doesn't require formal academic European training in music or sound. Anybody can do that. The other advantage of that, too, is you capture the multicultural richness within the room because people who have experiences in other kinds of 
cultures can bring that all into play in the work that they do. And that extends over to the classroom because many schools and urban centres in Canada have a very rich, multicultural flavour to the classroom, and of course students should be able to enrich others in that room with that different set of backgrounds-and the teacher needs to capitalize on that.

What role would you say the arts have played in teacher education in the last decade or so, and why?

The role that the arts have played in teacher education is very similar to the role that the arts have played in education, generally, and that is that we seem to be developing new approaches to education, particularly as through neuroscience we are understanding better how the brain works, it seems that when that literature is examined, the neuroscience of brain operations, when that is translated into educational practice, people seem to invent techniques in education which people in the arts have been using for very many years. That's particularly true in drama and visual arts where we talk all the time now about the validity of portfolio assessment. Well, visual arts teachers have been using that for years as a valid method of assessment-and it is, particularly a portfolio of accomplishment or a portfolio of evidence as accumulated over a year that's made up of a variety of different pieces of evidence. All of that is in the forefront of the evidence today about enlightened evaluation and assessment. Well, there's an example of something that's been going on for a long time.

The other is that as a society there's a culture we're learning that we kind of went too far in our technological degree of specialization, and we made people into experts in areas that nobody understood except other experts in the same area-that's certainly true of academia-but it's true of science, of society as a whole...but we've taken that technological science motivation since Sputnik...you know, that's how it happened, and we've become so technologically oriented and scientifically oriented, so mechanically oriented, that we've forgotten other parts of ourselves: the spiritual self, the inner self, the holistic self, the emotional side of ourselves, we know for example you don't learn anything in school unless you're emotionally ready to learn-all those kinds of things, the things that the arts have always concentrated on; and so when you refer to, say, the last 10 years I think the great revelation is that new approaches to pedagogy today all seem to reflect what's been going on in the arts for a long time.

The term "creativity" now is used all the time to say that... business corporations could benefit from a creative approach to the working atmosphere, the working situation. 
Creativity has been inherent in the arts for a long time. The most important thing in teacher education, particularly here, and I don't think this one is especially different than any other, is to provide a dimension in creativity and aesthetic experience (or beauty) as part of a total program. That's necessary for a complete experience in education. Not only as training for these teachers to go out into schools, but also because these student teachers are themselves not widgets. They're human beings, too, so for their own nourishment as well as the training to provide that for kids in schools. I think that is the major accomplishment and contribution of the arts in teacher education (as you said) in the last 10 years.

\section{What do you feel teacher education institutions should be doing to enhance the arts?}

They should be recognizing the importance of the arts to the overall development of teachers, and therefore, students, in schools. They don't sufficiently recognize it. The mindset about the arts in teacher education is similar to the mindset about the arts, generally, particularly in English Canada. French Canada, less so, but in English Canada we're still stuck with the idea that the arts are entertainment, they're frivolous, if you're interested you can pursue them on your own. It's not really part of a necessary, formal education, at public expense.

Backers of education, I think, across the country should recognize more clearly and more definitely that the arts within those institutions are as an important part in the development of teachers-and ultimately kids in schools-as important as what we would refer to as literacy and numeracy, which are the big buzzwords in this province. The "artistry" or some other term about that-I think Elliott Eisner coined that termis just as important because, otherwise, we're not total human beings. So there's an area that faculties of education and universities in general should recognize more than they do.

Can you suggest any ways that administrators can be convinced that this should be an integral part of a bachelor education program?

Well, the first obvious way is to make sure the arts programs available for teacher education match the curriculum guidelines that each province has in their schools. In this province, in Ontario, the elementary curriculum guidelines for all Ontario schools requires that each of dance, drama, music, and visual arts be taught to the level of the expectations listed in those documents. In this province, that is not possible, if you see 
that reflected in the programs of teacher education. Not possible here at this one; and most of the other faculties don't. They have limited opportunities to explore the arts: many have music options, some have visual arts, far fewer have drama, and almost none have opportunities in dance. At this one, we fuse all the arts together in our training for elementary teachers and we call it "integrated arts." We don't teach any of the discrete disciplines separately, we teach them all as if they're a united whole. And I have to believe that's the correct way to do it at the elementary level; but we need to do more of that, so administrators need to feel that the financial aspect of that is as important as anything else, and they don't currently. Certainly, here we need to continue to push for that all the time, and we do that with...right here we do a lot of optional things, enrichment activities.

We just finished a weekend called the "Creativity and Aesthetic Experience Weekend," where we presented a program to anybody who wanted to spend the weekend with us here in this building, and we provided all kinds of opportunities to investigate creativity in science and math, aesthetic experiences in social sciences, and many other areasit's not just about the arts, it's about that centrality of concepts, two of them: creativity and aesthetic experiences together, and that can be in any subject area, not just the arts, it can be anywhere in school life.

\section{What can schools and individual teachers do to enhance the arts in education?}

I think they should see that, again, aesthetic experience is as important in the lives of students as anything else, and I would suggest as a primacy, because I said earlier that if students are not emotionally ready to learn, they're not going to learn. If they come to school and they just learn their parents are divorced before they go to school, they're not going to learn anything that day. I think teachers need to help students become emotionally ready. Which means understanding that feelings are as important as cognition and being able to cope with the experiences at school, so part of your programming seems to me, needs to take into account the nourishment of a sense of trust, of relaxation, of security, of being able to take risks, of all of those kinds of perceptions and attitudes within a school that allow students to feel that they can investigate other things, that they can risk looking like an idiot in front of others, in order to truly understand whatever the concepts are being studied in any subject. Otherwise, they spend the whole time sitting in school-of course they sit too much, that's another problem-trying to figure out what the teacher wants them to say, what's the right answer or the wrong answer. 
The whole dichotomy of trying to express to the teacher something that will allow the teacher to give them a high mark, or something... all that kind of thing. Whereas, if you're going to spend five hours a day at school for 200 days a year, surely the experience of being there has to mean something to them in a holistic way, in a feeling way, as well as strictly in a rational, logical, sequential thinking way. Teachers and schools need to recognize that more than they do now; and the main opportunity providing that currently with people who understand it are people associated with the arts.

Do you have a favourite story of a student who experienced art for the first time and changed dramatically as a result?

I once taught at a secondary school that was a learning-disabled school for the entire district. We had a lot of students who had been labelled "learning disabled" for one reason or another. I taught one student who had a terrible stutter. It was painful to listen to and, I'm quite sure, painful for him too, to experience that on a daily basis. And he took a drama class that I taught. And he suddenly found that when he was playing a role that was different from himself, he didn't stutter any more. He also discovered that when he sang, he didn't stutter; and he discovered that in that school-and he was, what? In grade 10 or something - when he first discovered that he could be in an environment where he didn't stutter at all. Of course, he began to love going to drama class and vocal music class. He loved that too. So, there's two examples where somebody who had a very serious affliction-obviously, in part, because of a socio-somatic emotional trauma or something about his emotional matrix-which did not permit him to have a sense of calmness or freedom to be able to speak without stuttering all the time. And when he discovered that it was miraculous. His parents thought it was a miracle that he actually performed in a school play, that they went to see, because they found he didn't stutter either when he was doing the lines of a character in a play-in other words, he knew ahead of time what he was going to say; it was a script-but even when he improvised he knew it was play, it wasn't real, and he didn't stutter.

And that was one example that was particularly outstanding. But I noticed that with many students, particularly the learning-disabled students for one reason or another-not always stuttering; it could be some other issue - that in an arts classroom, particularly visual arts, particularly drama, often music (vocal music usually), they didn't display those disabilities. So, if you were looking for evidence, that particularly shows the value of arts in schools, look at the learning disabled evidence and their encounters with the arts - there's lots of evidence... how they almost are miraculous in allowing 
people to feel that they can overcome those disabilities because there's no risk of looking like an idiot or feeling like one.

I thought I'd ask you a little bit about the National Roundtable for Teacher Education in the Arts. Can you tell us what it does and your role there?

That was initially an experiment between me and the National Arts Centre...l do a lot of work with the national cultural institutions in the Ottawa area-and we had been thinking that academics meet a lot but mostly to discuss their research. Not as much about what they actually teach or how they teach; this is particularly true in the arts. And it seemed to me that there wasn't a regular forum for people in the arts to meet together to talk about that; so we felt there was some kind of need for that so four years ago we decided to co-host what we called a "roundtable." We wanted to call it a "roundtable" because we didn't want it to be a conference where there were presenters and people... it wasn't that kind of formal thing. We wanted it to be more of an informal discussion, so in the first year we had about 60 people from across the country who came to Ottawa in May for a couple of days and we were at the National Arts Centre, and it was kind of walking the talk about creativity and aesthetic experiences, in that we involved people in some experiences as well as opportunities to talk or discuss things.

That first year, for example, we had somebody on this faculty who, believe it or not, has done a PhD thesis on "hula hooping," and so we had them all doing "hula hooping" on the balconies of the National Arts Centre-just to look ridiculous with each other, and we have that on video for anybody that wants a copy! And we did other things like that. For example, there was a show on at the Arts Centre about tap dancing, so we had the creator of the tap dancing sequence come and give us a tap dancing workshop. And these were experienced professors and arts teachers from across the country, so we wanted to have a different forum for them to discuss what it is they do in the classroom. And-actually the original idea was only to do it once-but they said, "We want to do it again." So we had a second one, and the second one was not at the Arts Centre. We went to the National Gallery for that one because we felt that the setting, the ambience, the atmosphere was as important as what we were doing...I work a lot with the National Gallery, so we co-presented with them the second year... and the basic idea was the same: to mix small-group discussion and larger groups, and try to provide some experiences.

I think in that year we explored some of the things that were on exhibit at the time and we had some impromptu dance experiences that occurred in some of the public 
galleries, and some of it was quite outrageous, which was exactly the idea-and we decided then that we'd hold it regularly, once a year. We probably have about 200 people on the listserv for the Roundtable... and we have about 50 people generally speaking, who come, and we invite them from across the country, and they do come from across the country-most of them, of course, within a 500-mile radius of Ottawa (because of the ease of travel) and sometimes we try to tie it into the CSSE gatherings, as we're going to be doing this year which, this year the CSSE happens to be here... and so we're trying this year two or three days just before that, so people coming to do something like CSSE will just happen to come to our place on the way.

So, really it's kind of an informal forum for anyone from across the country who's involved in any way in teacher education in the arts, and that's obviously Faculty of Education people, but also school board consultants, superintendents, because that's in-service education as well as pre-service, and artists-a lot of artists come who are involved in that kind of training with teachers. And we get school board administrators, we get administrators and bureaucrats from the Ministry of Education. In Ontario we have a college of teachers, it's called "The Ontario College of Teachers," that regulates the teaching profession including qualifications, so we've been lucky that we've had representation from them every year in the four years that we've done it. And we try to go to different environments each year, but places that have a kind of ambience and a special nature about them. Last year, we were at the Bytown Museum, The National Gallery, The National Arts Centre, and another art gallery in Ottawa. Some people were actually walking a lot between venues, and those walks themselves were part of the process. There's a lot in the literature about the value of walking to stimulate creative thought, and so we were mining that, exploring that. This year, we're (it's not final yet) thinking of being at the Canadian Museum of History and a number of other surprise locations. It's May 28th and 29th, 2015.

\section{Do you think a similar kind of thing could be developed for students in schools?}

Oh, what a great question! My short answer is: absolutely! Yes, and of course, one group we don't have at the National Roundtable are students in schools. We do get student teachers, and we get graduate students, but we don't get students themselves-who should, of course, have their own. In Ottawa, there is a community group called "The Advisory Committee on the Arts," for the Ottawa-Carleton District School Board: this is a community organization of volunteers who advise the trustees of the school board on all matters of arts education; to that committee are student representatives from the schools of this school board. That is one example of a local 
community of interested arts people advising a school board and they're not made up of the employees of the school board so they're providing, in a sense, unbiased information about arts enrichment in the schools. And there are students who are members of that. But your question was about could the students collectively organize their own autonomous roundtable, or whatever they'd call it, I think it's a great idea. I don't think it exists at the moment. And should.

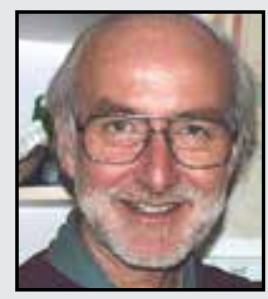

Michael Wilson has a Bachelor of Arts degree from McGill University and Masters and Doctorate degrees from the University of Toronto (OISE). He has been a classroom teacher in several schools and faculty of education professor in the arts since 1967. Michael has been a public arts education advocate for many years through involvement in provincial and national organizations in Canada and abroad and has often initiated new movements and organizations in the areas of teacher education in the arts, civic and provincial arts policy, and the roles of artists in schools. He is a frequent speaker and published author on all the above topics, locally, nationally, and internationally.

\section{LINK TO:}

http://code.on.ca/blog/national-roundtable-teacher-education-arts-draft-report www.nrtea.ca 